\title{
Perceived risk on smoking behavior and perception toward parenting style as predictors of smoking risk behavior in adolescents
}

\author{
Mayenrisari Arifin \\ Department of Psychology \\ Hasanuddin University \\ Makassar, Indonesia \\ mayen_57@yahoo.co.id
}

\author{
Sukma Khasanah \\ Department of Psychology \\ Hasanuddin University \\ Makassar, Indonesia \\ sukmakhasanah@gmail.com
}

\author{
Grestin Sandy R \\ Department of Psychology \\ Hasanuddin University \\ Makassar, Indonesia \\ grestin_sandy@yahoo.com
}

\begin{abstract}
Adolescents are expected to have been able to distinguish any kind of behavior that has either positive or negative impact on themselves. However, there is a high prevalence in adolescents who tend to engage in risky behavior. One of the most worrying behaviors is smoking behavior. The purpose of this research is to determine how significant are the perceptions of smoking risk and parenting style in predicting adolescent smoking risk behavior. This research was participated by 145 adolescents (age 15-20) which were selected by purposive sampling technique. Multiple linear regression method is used to analyze and the data.
\end{abstract}

The results were found that the perception of smoking risk and parenting style are significant to predict adolescent smoking risk behavior. The most significant dimension of risk perception in predicting adolescent smoking risk behavior is dread risk dimension; which means the more adolescents fear the risks of smoking, the less they will smoke. The most significant parenting style in predicting adolescent smoking risk behavior is authoritative; which means the more adolescents have an authoritative parenting style, the less likely they will smoke.

Keywords: Smoking risk behavior; perceived risk; parenting style; adolescence

\section{INTRODUCTION}

Adolescence is a period of transition from childhood to adulthood. This period is a fun, as well as hardest time in life. This is because adolescents are confused about their identity and role they should play. Adolescent are no longer children, but not adult yet. [1]

One of the development task of adolescent is to be able to use their body effectively, feel proud, able to accept and to be tolerant to the body changes that occur [1]. Adolescents should also be able to keep their body healthy by trying to protect it from things that can harm the body such as abuse of drugs, alcohol, smoking and so on [2]. However, in a survey data of adolescent reproductive health in Indonesia in 2012, the prevalence of adolescents (men and women) who drink alcohol, drug abuse, smoking and so on are alarming [3]. Based on this data, it can be inferred that there is high prevalence of adolescents who conduct risky behavior. It seems there is a tendency in adolescents to do negative things which can lead to negative impact and harm their body.

Based on prior research, there are several factors influencing adolescent to smoke. According to research by Sarafino \& Smith, family factor, specifically parenting style and risk perception are influencing adolescent behavior to smoke [4]. Family and parenting style should provide ideal interaction between parents and children, including care, protection and education of how to behave in accordance to norms that existed in the community, without harming their self and others. However, there are parents who tend to provide less control on their children and give their children freedom to do anything they want. As a consequence, teenagers tend to behave in a way that violates norms and values in the community [5].

The next factor is risk perception. Ralph [6] argues that smoking behavior is influenced by perceptions of risk. Adolescent tend to fail to perceive smoking as risky behavior thus influence their tendency to smoke. Ideally, because of their cognitive development, adolescent should be able to distinguish which behavior have a positive impact on them, and which not. However, as Skaar [7] proposes, adolescents who engage in risky behavior have a low perception of risk. Adolescents consider that the negative consequences of such risky behavior are low

This paper aims to examine to what extent perception of risk on smoking behavior and parenting style predict adolescent smoking risk behavior. Parenting style in this case is seen from adolescent perception of parenting style, which consists of authoritarian, authoritative, neglectful, and permissive. In addition, perceived risk consists of nine dimensions, which are: Involuntariness of risk, Immediacy of effect, known to Expose of Risk, Uncontrollability over Risk, Newness, and Catastrophic of risk, Dread Risk, and Severity of Consequences. 


\section{LITERATURE REVIEW}

\section{A. Smoking Risk Behavior}

Smoking risk behavior refers to behavior of smoking cigarette. Chown propose that smoking behavior is a risky behavior that is prevalent nowadays [8]. It is risky because it can harm adolescents' health, as well as hinder their optimal development. Although in the short term the negative effect may have not occurred, the long term effect is dangerous, even fatal. In addition, smoking behavior also can trigger other riskier behavior, such as smoking marijuana, and drug abuse.

\section{B. Perceived Risk on Smoking Behavior}

Perception of the risk on smoking behavior refers to individual's assessment of possible danger as consequences of smoking as well as to what extent do individual perceived the importance of the negative consequence. There are nine dimensions of risk perception, which are used to predict perception of risk. The nine dimensions are: Unvoluntariness of risk, Immediacy of effect, Known to Expose of Risk, Known to Science of Risk, Uncontrollability Over Risk, Newness, Catastrophic of risk, Dread Risk, dan Severity of Consequences [9]

\section{Perception to Parenting Style}

Parenting is defines as an interaction between parents and their children. Ideal parenting provides an ideal interaction in which parents provide care, protection and education to their children, to behave in accordance to values and norms in society [10]. In interaction with their children, parents develop sets of attitude toward their children which influence their interaction with their children, which called by parenting style. Parenting style may differ among parents [11]. Furthermore, how parents perceive their parenting style may differ to how children perceive the parenting style of their parents. This is due to parenting may be perceived subjectively by children [12].

Perception of parenting style refers to individual's perception of how parents interact, educate, guide and protect him/her to behave in accordance with the values and norms that applied in community. The parenting style type is divided into four: authoritative, authoritative, neglectful, and permissive parenting style [10].

\section{METHOD}

\section{A. Participants}

There were 145 participants were selected by purposive sampling. Participants were selected by criteria as follow:

1. Adolescent aged 15-20 years.

2. Smoker

3. Living in the city of Makassar.

\section{B. Procedures}

Data collection were done in December 21, 2016 to January $13^{\text {th }}, 2017$. There were 160 questionnaires distributed in Schools, college, and several residential areas. From 160 distributed questionnaires, there were 15 questionnaires which could not be used because participants who filled in the questionnaire were not meet the selection criteria.

\section{Measures}

There were three measures, employed in this study. The first measure was perceived risk of smoking behavior. Investigator constructed the scale based on perceived risk by Slovic [9]. Accordingly, perceived risk consists of 9 dimensions, which are: Involuntariness of risk, Immediacy of Effect, Known to Expose of Risk, Known to Science of Risk, and Uncontrollability over Risk, Newness, and Catastrophic of risk, Dread Risk, and Severity of Consequences.

The second scale was perception to parenting style scale. Investigator based on Maccoby and Martin parenting scale constructed this scale. There were four types parenting style which sere: Authoritative, authoritarian, Neglectful, and Permissive parenting [10].

The third scale was smoking risk behavior. Investigator constructed this scale based on risk characteristics status as proposed by Chown [8]. There were three statuses of risk: low risk, moderate risk and high risk

\section{RESULT}

\section{Multiple regression model I}

Multiple regression was employed to analyze relation between perception of parenting style and perceived risk of smoking behavior in predicting smoking risk behavior. In this model dummy variable was applied to perception of parenting style variable. The result of the regression analysis can be seen in Table I.

TABLE I. REGRESSION MODEL I

\begin{tabular}{lllll}
\hline Model & R & R Square & $\begin{array}{l}\text { Adjusted R } \\
\text { Square }\end{array}$ & $\begin{array}{l}\text { Std. Error of } \\
\text { the Estimate }\end{array}$ \\
\hline 1 & 0.445 & 0.198 & 0.175 & 6.53618 \\
\hline
\end{tabular}

Based on table I, it can be seen that can be seen that the Adjusted R square obtained is 0.175 . It shows that perception of parenting style and perception of smoking risk predict $17.5 \%$ risk of smoking behavior. Thus, the rest of $82.5 \%$ is influenced by factors other than the variables measured in this study.

\section{Multiple regression model II}

The second regression model is multiple linear regression on aspects of perceived risk as predictor and smoking risk behavior as outcome variable. 


\section{TABLE II. REGRESSION MODEL II}

\begin{tabular}{lllll}
\hline Model & $\mathrm{R}$ & R Square & $\begin{array}{l}\text { Adjusted R } \\
\text { Square }\end{array}$ & $\begin{array}{l}\text { Std. Error of } \\
\text { the Estimate }\end{array}$ \\
\hline 1 & 0.727 & 0.528 & 0.497 & 5.08748 \\
\hline
\end{tabular}

Table II presents Adjusted R square is 0.497 that shows that dimensions of perceived risk, which are Involuntariness, Immediacy of effect, known to expose risk, known to science risk, Uncontrollability Over Risk, newness, catastrophic of risk, dread risk, Severity of Consequences are significantly predict smoking risk behavior as much as $49.7 \%$.

However, analysis on each dimension shows that only 5 dimensions that are significant in predicting adolescent risk behavior, namely involuntariness dimension, known to expose risk dimension, newness dimension and dread risk dimension. In contrast, immediacy of effect dimension, catastrophic of risk dimension, Uncontrollability over Risk dimension, Severity of Consequences dimension and known to science risk dimension are not significant in predicting smoking risk behavior.

\section{Multiple Regression model III}

The third multiple regression was conducted on perception of parenting style as predictor variable, and smoking risk behavior as outcome variable.

TABLE III. REGRESSION MODEL III

\begin{tabular}{|c|c|c|c|c|}
\hline Model & $\mathrm{R}$ & R Square & $\begin{array}{l}\text { Adjusted R } \\
\text { Square }\end{array}$ & $\begin{array}{l}\text { Std. Error of } \\
\text { the Estimate }\end{array}$ \\
\hline
\end{tabular}

\begin{tabular}{lllll}
\hline 1 & 0.493 & 0.243 & 0.221 & 6.33052 \\
\hline
\end{tabular}

Table III presents determinant Coefficient of Adjusted $\mathrm{R}$ square .221 that indicates that perception on parenting style which consists of authoritative, authoritarian, neglectful and permissive parenting style simultaneously predict smoking risk behavior as much as $22.1 \%$.

However, only authoritative parenting style can significantly predict Smoking risk behavior. On the contrary, authoritarian parenting style and permissive parenting style and neglectful parenting, are not significant in predicting smoking risk behavior.

\section{DISCUSSION}

This study was conducted to gain a deeper understanding of how adolescents, who based on the stage of cognitive development are able to distinguish good behavior and bad for himself is still smoking which is a risky behavior. Smoking is categorized as a risky behavior because this can impair health, hinder adolescent optimal development, and initiate other risky behaviors [8].
The result of this study shows that perceived risk on smoking behavior and perception toward parenting style are significant predictors to adolescent smoking risk behavior $\left(R^{2}\right.$ $.175, p<.05)$. However, only authoritarian parenting style can significantly predict smoking risk behavior. Specifically, parenting which is perceived by adolescent as authoritarian parenting style has is significantly lowering the tendency to engage in risky smoking behavior in adolescent will result in negative relationship.

The results of this study are in line with prior studies which propose that there is a significant influence between parenting style of behavior against adolescent risk of smoking [13]. Parents that provide rules regarding smoking behavior, and parent history of smoking behavior influence children smoking behavior. In addition, adolescent who perceive authoritative parenting style tend to have a small chance to start smoking and have a low smoking behavior or tend to have the intention to quit smoking [14].

According to Baumrind, authoritative parenting styles tend to provide guidance rather than coercion, thus adolescent 1 form behaviors that avoid risky behaviors. However, the presence of some subjects with high smoking risk behaviors who had an authoritative parenting perception are $28 \%$ and the majority of adolescent participants who smoked in this study had a perception of authoritative parenting style. One reason for this finding is that in addition to parenting style perception, there are other factors that influence adolescents in smoking behavior, such as peers, social media and factors in their own teenagers.

The findings of this research propose that dimensions of risk perception on smoking behavior are significant to predict adolescent smoking risk behavior, thus, it very important to provide sufficient knowledge to adolescent about the risk of smoking. Adolescents need to know the negative effects of such risk behavior so that they can minimize the onset of physiological and psychological disorders. When the information and understanding has been experienced by adolescents, the need for consistency from parents by applying the discipline and openness in communication. This can help the relationship between adolescents and parents to better recognize the psychological condition of adolescents and to help them solve adolescent' $s$ problem together. Thus, perceived risk on smoking behavior can be increased, whilst lowering the smoking behavior.

\section{VI.CONCLUSION}

This study was set to investigate the contribution of perceived risk on smoking behavior and perception toward parenting style in predicting adolescent smoking risk behavior. The result of this study shows that perceived risk and perception toward parenting style are significant predictor to smoking behavior in adolescent. However, only authoritative in dimension for perception to parenting style that is significant to smoking behavior whilst in dimension of perceived risk only Involuntariness of risk, Immediacy of effect, Known to Expose of Risk, Uncontrollability Over Risk, Newness, Catastrophic of risk, Dread Risk, and Severity of Consequences which are 
significant to smoking behavior in adolescent. Based on the result of this study, we believe it is important for parent to provide discipline as well as communication with their adolescent children so hopefully, the perceived risk on smoking behavior will be heightened while at the same time, the intensity or intention to smoke will be lower.

\section{REFERENCES}

[1] E.B. Hurlock. Psikologi Perkembangan Suatu Pendekatan Sepanjang Rentang Kehidupan. Jakarta : PT. Erlangga. 1980.

[2] Utah Education Network. (2015). Developmental Tasks (Adolesence). Internet:http://www.uen.org/cte/family/child_development/downloads/gr owth/developmental.pdf..

[3] Badan Pusat Statistik, BKKBN \& Kemenkes. "Survei Demografi dan Kesehatan Indonesia 2012." Jakarta: Measure DHS \& ICF Internasional (2012). 2013.

[4] E.P. Sarafino \& T.W. Smith. Health psychology: Biopsychosocial interactions. John Wiley \& Sons. 2011.

[5] R. Wijaya \& A. Sajidah. Hubungan Pola Asuh Orang Tua dengan Kejadian Merokok Pada Siswa SMA Negeri 1 Tanjung Kabupaten Lombok Utara. 2015.

[6] J. Ralph, S. John, Santelli, and A. Richard, Crosby, eds. Adolescent health: Understanding and preventing risk behaviors. John Wiley \& Sons. 2009.
[7] N. R. Skaar. Development of the adolescent exploratory and risk behavior rating scale (Doctoral dissertation, University of Minnesota. 2009.

[8] P. Chown. Understanding Risk Taking Behavior. 2014.

[9] Hyunhi, dkk. Risk Communication. Los Angeles. 2015.

[10] N. L. P. Y. Sanjiwani \& I. Budisetyani. Pola asuh permisif ibu dan perilaku merokok pada remaja laki-laki di SMA Negeri 1 Semarapura. Jurnal Psikologi Udayana, 1(02). 2014.

[11] B. W. C. Putro. Hubungan Antara Persepsi Terhadap Gaya Pengasuhan Authoritative Dengan Regulasi Emosi Dalam Menghadapi Ujian Pada Remaja (Doctoral dissertation, Universitas Muhammadiyah Surakarta). 2013.

[12] R. Wulaningsih, \& N. Hartini. Hubungan antara persepsi pola asuh orang tua dan kontrol diri remaja terhadap perilaku merokok di pondok pesantren. Jurnal psikologi klinis dan kesehatan mental. Vol. 4 No. 2. 2015.

[13] R.M. Huver, R.C. Vermulst, and H. de Vries. "Is parenting style a context for smoking-specific parenting practices?". Drug and Alcohol Dependence, vol. 89, pp.116-125. 2007

[14] K. Newman, L. Harrison, C. Dashiff, and S. Davies, S. "Relationships between parenting styles and risk behaviors in adolescent health: An integrative literature review." Revista Latino-Americana de Enfermagem (RLAE), vol. 16(1), pp.142-150. 2008

[15] D. Baumrind. "Patterns of parental authority and adolescent autonomy." New directions for child and adolescent development, vol. 108, pp. 6169. 2005 